\title{
Exploring the selenium isotope record in the Archean mantle
}

\author{
MARIA I. VARAS-REUS ${ }^{1}$, STEPHAN KÖNIG ${ }^{1}$, REGINA \\ NEUBAUER $^{1}$, AIERKEN YIERPAN ${ }^{1}$, LUISE J. WAGNER, \\ $\mathrm{MA}^{2}$, JEAN-PIERRE LORAND ${ }^{3}$ AND RONNY \\ SCHOENBERG $^{1}$ \\ ${ }^{1}$ University of Tuebingen \\ ${ }^{2}$ University of Tuebingen \\ ${ }^{3}$ National Museum of Natural History \\ Presenting Author: mvarasreus@gmail.com
}

Selenium (Se) isotopes have arisen as a promising tool to address the Earth's volatile origin and evolution. In a recent study, we reported the selenium isotope composition of postArchean mantle peridotites and discussed their role in providing a Bulk Silicate Earth signature [1]. To better understand the Earth's mantle volatile evolution, we explore the Se isotope record in the Archean mantle. Preliminary data of mantle peridotites from the Kaapvaal Craton (3.3-3.5 Ga) in South Africa show larger Se isotope variations than the average postArchean mantle peridotites. Therefore, it is intriguing to envisage a scenario where the observed isotopic variability might indicate ubiquitous pre-late veneer mantle domains that escaped complete equilibration with the late accreted chondritic materials, as previously invoked in other studies (e.g., [2], [3]). However, a firm assessment of secondary, non-magmatic processes like volatile-escape during emplacement and even supergene weathering is necessary before such conclusions can be drawn. For a broader picture, we will further include komatiites from the 3.5 Ga Komati formation of the Barberton Greenstone Belt (South Africa) and the $2.7 \mathrm{Ga}$ Abitibi Greenstone belt (Canada) in this investigation.

[1] Varas-Reus et al. (2019) Nature Geoscience 12, 779-782; [2] Willbold et al. (2015) EPSL 419, 168-177; [3] Fischer-Gödde et al. (2020) Nature 579, 240-244. 